\title{
The evaluation of corneal endothelial permeability in PERK study patients*
}

\author{
JANET B SERLE,' PENNY A ASBELL,' STEPHEN A OBSTBAUM', \\ STEVEN M PODOS, ' AND NGOC ANH-LE
}

From the Departments of 'Ophthalmology and ${ }^{2}$ Biostatistics, Mount Sinai School of Medicine, City University of New York, USA

SUMmarY Sixteen patients enrolled in the PERK study were evaluated by fluorophotometry 24 hours or six months following radial keratotomy. A comparison of eyes operated and not operated upon showed that endothelial permeability was not significantly altered 24 hours and six months after surgery. Aqueous humour flow rates and anterior chamber elimination coefficients were significantly higher 24 hours after surgery in the eyes operated on than in those not operated on. Six months after surgery there was no longer a significant difference in these factors. The increase in aqueous humour flow rates 24 hours after surgery may represent a subclinical breakdown in the blood-aqueous barrier.

Anterior radial keratotomy, a surgical procedure for the correction of myopia, is at present being evaluated by the PERK (Prospective Evaluation of Radial Keratotomy) study, to determine the predictability, safety, and short and long term effects of the surgery. The operation, as originally performed by Sato, consisted of anterior and posterior radial corneal incisions. Unfortunately, as many as $75 \%$ of his patients developed bullous keratopathy $10-15$ years after surgery. ${ }^{23}$ Because of this severe complication, the surgery was altered by Fyodorov and Durnev ${ }^{4}$ to consist of only anterior radial corneal incisions. We carried out a study to evaluate the effect of anterior radial keratotomy, performed according to the PERK surgical protocol, ${ }^{5}$ on endothelial cell function, measured by fluorophotometry.

\section{Subjects and methods}

Seventeen of the 38 patients enrolled in the PERK study $^{5}$ at the Mount Sinai Medical Center between December 1982 and October 1983 agreed to undergo fluorophotometry. One patient was excluded from the study owing to difficulty in data interpretation.

*This study was presented in part at the Association for Research in Vision and Ophthalmology Meeting, Sarasota, Florida, 4 May, 1984.

Correspondence to Janet B Serle, MD, Department of Ophthalmology, Mount Sinai Medical Center, One Gustave L Levy Place, New York, NY 10029, USA.
Eleven patients were examined by fluorophotometry 24 hours after surgery and five patients six months after surgery.

Six of the patients examined 24 hours after surgery were male and five were female. Six had the right eye operated on, five the left eye. The patients were between 22 and 46 years of age, average 29 (SD 8) years. Preoperative spherical equivalent varied between -2.25 dioptres and -4.75 dioptres.

Five patients underwent fluorophotometry six months after radial keratotomy, three male and two female. Two patients had the right eye operated on, three the left eye. These patients were between 22 and 38 years of age, average 32 (SD 7) years. The preoperative spherical equivalent varied between -2.00 dioptres and -8.00 dioptres.

Radial keratotomy was performed by one of us (SAO) according to the PERK surgical protocol. ${ }^{5}$ It consisted of eight radial anterior corneal incisions to $100 \%$ of the depth of the thinnest paracentral area, measured with an ultrasonic pachymeter. A central 3 to $4 \mathrm{~mm}$ optical clear zone was left untouched, depending on the preoperative refraction, and the incisions did not extend past the limbus. In no case was the anterior chamber entered during surgery.

Fluorophotometry was performed with a slit-lamp fluorophotometer. Fluorescein sodium $0.25 \%$ and $0.4 \%$ benoxinate hydrochloride (Fluress, BarnesHind) was applied topically to both eyes, one drop every three minutes for 10 doses. Measurements of 
fluorescence in the cornea and in the anterior chamber were begun two and a half hours after fluorescein application and continued every 20 minutes for four hours. The unoperated eye served as the control eye, and was compared with the operated eye in these experiments.

The data were analysed by a computerised model according to the method of Jones and Maurice ${ }^{6}$ on the assumption of an anterior chamber volume of $175 \mu \mathrm{l}$ and a corneal volume of $70 \mu \mathrm{l} . \mathrm{K}_{\mathrm{o}}$, the anterior chamber elimination coefficient; $\mathrm{K}_{\text {cac }}$, the cornea-toaqueous transfer coefficient; $K_{\mathrm{aac}}$, the corneal transfer coefficient referred to the volume of the anterior chamber; and F, the aqueous humour flow rate, were calculated. Corneal endothelial permeability was calculated on the assumption of a corneal stromal thickness of $0.47 \mathrm{~mm}$. The unoperated control eyes were compared with the operated eyes for statistical analysis.

Gross outflow facility was measured on four patients at 24 hours and at one year after the initial radial keratotomy on the second eye, and on one patient at 24 hours and at one year after the second procedure on the second eye. Outflow facility was measured for four minutes on each eye with an electronic Schiøtz tonometer. In three of these five patients the intraocular pressure was measured with a Goldmann applanation tonometer 24 hours and one year after surgery. The scleral rigidity in these three patients was calculated 24 hours and one year after surgery by the Friedenwald nomogram, the applanation intraocular pressure, and the initial intraocular pressure from the tonographic tracing. For statistical analysis the most recently operated eye was compared with the eye which had undergone surgery one year previously.

The paired $t$ test was used to compare the treated and contralateral control eyes.

\section{Results}

Twenty-four hours after radial keratotomy was performed on 11 patients there was no significant difference in $\mathrm{K}_{\mathrm{cac}}, \mathrm{K}_{\mathrm{aac}}$, and the endothelial permeability in a comparison of operated and unoperated eyes (Table 1$). \mathrm{K}_{\mathrm{o}}$ was significantly $(\mathrm{p}<0.001)$ higher in the operated eye, $2 \cdot 2 \pm 0 \cdot 6 \mathrm{~min}^{-1}($ mean $\pm \mathrm{SD}$ ), compared with the unoperated eye, $1.5 \pm 0.6 \mathrm{~min}^{-1}$. F was significantly $(p<0.001)$ higher in the operated eye, $3.9 \pm 1.0 \mu \mathrm{l} / \mathrm{min}$, compared with the unoperated eye, $2 \cdot 6 \pm 1 \cdot 1 \mu \mathrm{l} / \mathrm{min}$.

Six months after radial keratotomy there was no significant difference in $\mathrm{K}_{\mathrm{cac}}, \mathrm{K}_{\mathrm{aac}}$, endothelial permeability, $\mathrm{K}_{\mathrm{o}}$, or $\mathrm{F}$, in a comparison of operated and unoperated eyes in five patients (Table 2).

Gross outflow facility was significantly $(p<0.05)$
Table 1 Fluorophotometry performed on 11 patients 24 hours after radial keratotomy

\begin{tabular}{|c|c|c|c|c|c|}
\hline \multirow[b]{2}{*}{ Operated } & \multirow{2}{*}{$\begin{array}{c}\begin{array}{l}K_{\mathrm{cac}} \\
10^{-3} \\
\mathrm{~min}^{-1}\end{array} \\
\begin{array}{c}4 \cdot 3 \\
\pm 0 \cdot 9 \dagger\end{array}\end{array}$} & \multirow{2}{*}{$\begin{array}{c}\begin{array}{l}K_{\mathrm{aac}} \\
10^{-3} \\
\min ^{-1}\end{array} \\
\begin{array}{r}1.7 \\
\pm 0.4\end{array}\end{array}$} & \multicolumn{2}{|c|}{$\begin{array}{l}\text { Endothelial } \\
\text { permeability } K_{\mathrm{o}} \\
10^{-4} \mathrm{~cm} / \mathrm{min} 10^{-2} \mathrm{~min}\end{array}$} & \multirow{2}{*}{$\begin{array}{r}\begin{array}{l}F \\
\mu l / m i n\end{array} \\
3 \cdot 9^{*} \\
\pm 1 \cdot 0\end{array}$} \\
\hline & & & $\begin{array}{r}3.2 \\
\pm 0.7\end{array}$ & $\begin{aligned} & 2 \cdot 2^{*} \\
\pm & 0 \cdot 6\end{aligned}$ & \\
\hline Unoperated & $\begin{array}{r}4.0 \\
\pm 1.3\end{array}$ & $\begin{array}{r}1.6 \\
\pm 0.5\end{array}$ & $\begin{array}{r}2.9 \\
\pm 1.0\end{array}$ & $\begin{array}{r}1.5 \\
\pm 0.6\end{array}$ & $\begin{array}{r}2 \cdot 6 \\
\pm 1 \cdot 1\end{array}$ \\
\hline
\end{tabular}

*Significant difference between operated and unoperated eyes, paired $t$ test, $\mathrm{p}<0 \cdot 001$. †Mean \pm SD.

Table 2 Fluorophotometry performed on five patients six months after radial keratotomy

\begin{tabular}{|c|c|c|c|c|c|}
\hline \multirow[b]{2}{*}{ Operated } & \multirow{2}{*}{$\begin{array}{c}\begin{array}{l}K_{\mathrm{cac}} \\
10^{-3} \\
\mathrm{~min}^{-1}\end{array} \\
\begin{array}{c}4 \cdot 0 \\
\pm 1 \cdot 1 \dagger\end{array}\end{array}$} & \multirow{2}{*}{$\begin{array}{r}\begin{array}{l}K_{\mathrm{aac}} \\
10^{-1} \\
\mathrm{~min}^{-1}\end{array} \\
\begin{array}{r}1 \cdot 6 \\
\pm 0 \cdot 4\end{array}\end{array}$} & \multicolumn{2}{|c|}{$\begin{array}{l}\text { Endothelial } \\
\text { permeability } K_{\mathrm{o}} \\
10^{-4} \mathrm{~cm} / \mathrm{min} 10^{-2} \mathrm{~min}\end{array}$} & \multirow{2}{*}{$\begin{array}{l}\begin{array}{l}F \\
\mu l / m i n\end{array} \\
3 \cdot 5 \\
\pm 1 \cdot 0\end{array}$} \\
\hline & & & $\begin{array}{r}2.9 \\
\pm 0.8\end{array}$ & $\begin{array}{r}2.0 \\
\pm 0.6\end{array}$ & \\
\hline Unoperated & $\begin{array}{r}4.0 \\
+1.5\end{array}$ & $\begin{array}{r}1.6 \\
\pm 0.6\end{array}$ & $\begin{array}{r}2.9 \\
\pm 1.1\end{array}$ & $\begin{array}{r}2.1 \\
\pm 0.7\end{array}$ & $\begin{array}{r}3.7 \\
\pm 1.5\end{array}$ \\
\hline
\end{tabular}

†Mean \pm SD.

higher in five patients in the newly operated eye, $0.55 \pm 0.09$ (mean $\mu \mathrm{l} / \mathrm{min} \mathrm{mmHg} \pm \mathrm{SD}$ ), compared with the eye which had been operated on the year before, $0 \cdot 39 \pm 0 \cdot 10 \mu \mathrm{l} / \mathrm{min} \mathrm{mmHg}$. Intraocular pressure, obtained from the tonograms, was not significantly different in a comparison of the recently operated and the previously operated eyes respectively, $12.5 \pm 3.5$ (mean $\mathrm{mmHg} \pm \mathrm{SD}$ ) and $14 \cdot 8 \pm 3 \cdot 2$ $\mathrm{mmHg}$. One year after surgery on the second eye the outflow facility was similar, $0.30 \pm 0.09 \mu \mathrm{l} / \mathrm{min}$ $\mathrm{mmHg} \pm \mathrm{SD}$ in the most recently operated eye, and $0 \cdot 31 \pm 0.13 \mu \mathrm{l} / \mathrm{min} \mathrm{mmHg}$ in the contralateral eye. The intraocular pressure measured with a Goldmann applanation tonometer was not significantly different in the treated eyes $12.0 \pm 1.2 \mathrm{mmHg}$ and the control eyes $13.0 \pm 3.7 \mathrm{mmHg}$ one year after surgery. The ocular rigidity in three of these patients was similar, $0.031 \pm 0.015( \pm S D)$ in the recently operated eye and $0.028 \pm 0.007$ in the contralateral eye 24 hours postoperatively, and $0.028 \pm 0.004$ and $0.026 \pm 0.003$ at one year in the most recently operated eye and in the contralateral eye, respectively.

\section{Discussion}

Endothelial permeability, as measured by fluorophotometry, was unaltered at 24 hours and six months after radial keratotomy. Our results on endothelial permeability are similar to those of Hull et al. ${ }^{7}$ in the rabbit. This group assessed endothelial permeability by measuring the flux of tritiated inulin 
and carbon-14 labelled dextran, and by fluorophotometry. They did not demonstrate a significant alteration in endothelial permeability to any of these three substances between 24 hours and 10 weeks after radial keratotomy. Rabbit corneal endothelium responds to injury by proliferation, ${ }^{8}$ in contrast to human corneal endothelium. Hull used the same inulin and dextran radioactive flux technique in the owl monkey and demonstrated a transient increase in endothelial permeability to inulin in the operated eyes two days after radial keratotomy, with a return to levels comparable to those of the unoperated eyes four weeks after surgery. Dextran permeability was unaltered two days and four weeks following the procedure. The monkey corneal endothelium showed a transient increase in permeability to the smaller $1.4 \mathrm{~nm}$ inulin molecule, but not to the larger $3.8 \mathrm{~nm}$ dextran molecule. The fluorescein molecule measures $0.5 \mathrm{~nm}$, but fluorophotometry was not performed on these monkeys. Recently Beatty and Smith $^{10}$ found a persistent increase in corneal endothelial permeability to fluorescein during the first three months following radial keratotomy in the owl monkey. Corneal endothelial permeability in these animals was not increased from six months to two years following surgery.

$\mathrm{K}_{\mathrm{o}}$, the transfer coefficient of aqueous out of the eye, was significantly $(p<0.001)$ increased 24 hours after surgery in our studies. This transient increase in $\mathrm{K}_{\mathrm{o}}$ may be due to a temporary alteration in the configuration of the anterior chamber, resulting in a temporary increase in outflow facility. Zimmerman $e t$ al. " demonstrated a decrease in outflow facility following removal of through-and-through sutures from penetrating keratoplasties in eye bank eyes. Gross outflow facility was significantly $(p<0 \cdot 05)$ higher in five patients in the newly operated eye, $0.55 \pm 0.09$ (mean $\mu \mathrm{l} / \mathrm{min} \mathrm{mmHg} \pm \mathrm{SD}$ ), compared with the eye which had been operated on the year before, $0 \cdot 39 \pm 0 \cdot 10 \mu \mathrm{l} / \mathrm{min} \mathrm{mmHg} \pm \mathrm{SD}$. Intraocular pressure, obtained from the tonograms, was not significantly different in comparisons of the recently operated and the previously operated eyes, $12 \cdot 5 \pm 3 \cdot 5$ (mean $\mathrm{mmHg} \pm \mathrm{SD}$ ) and $14.8 \pm 3.2 \mathrm{mmHg}$ respectively. The coefficient of ocular rigidity was similar in the eyes examined 24 hours after surgery and the contralateral eyes. One year after surgery the outflow facility was no longer significantly different in treated and control eyes. The intraocular pressure and the coefficient of ocular rigidity were also similar one year after surgery.

The increase in aqueous humour flow rates in the operated eye 24 hours after surgery may represent a real increase. More probably it represents a subclinical breakdown in the blood-aqueous barrier. Clinically these patients did not show cells or flare on slit-lamp examination postoperatively. A real increase in aqueous humour flow is difficult to explain after radial keratotomy. Hull et al. ${ }^{7}$ reported a decrease in aqueous humour flow rates, measured by fluorophotometry, in rabbits one and 10 weeks after radial keratotomy.

The stability of endothelial permeability to fluorescein at 24 hours and six months after radial keratotomy in humans is encouraging. Two factors must be emphasised. Firstly, fluorophotometry is a mass measurement of corneal endothelial function; very small variations in permeability, or localised alterations in endothelial cell function, may not become apparent with this technique. Secondly, six months is a relatively short-term evaluation of endothelial function. The corneas Sato operated on did not show bullous keratopathy until 10 or more years after surgery, ${ }^{2}$ and he was directly injuring the endothelial cells with the posterior incisions.

Other methods of evaluating corneal endothelium after radial keratotomy have included specular microscopy. Studies in animal models (monkeys) suggest cell loss of $10-15 \%$ in the early postoperative period, which does not appear to progress over a 1-2 year follow-up period. ${ }^{12} 13$ Several groups have looked at endothelial cell counts in humans and have found 0 to $10 \%$ cell loss in the central cornea, the amount depending on the study. Studies of the peripheral cornea, directly under the incisions, have also not demonstrated significant cell loss or alteration in the first year after surgery. ${ }^{14}$

Longer periods of endothelial evaluation postoperatively and more sensitive methods of evaluation would be helpful in determining alterations in corneal endothelial cell function after radial keratotomy.

This work was supported in part by NEI 5-RO1-EY03751 and $\mathrm{Y}-01867$, and an unrestricted grant from Research to Prevent Blindness, Inc., New York.

\section{References}

1 Sato T, Akiyama K, Shibata H. A new surgical approach to myopia. Am J Ophthalmol 1953; 36: 823-9.

2 Kanai A, Yamaguchi T, Yajima Y. The fine structure of bullous keratopathy after anteroposterior incision of the cornea for myopia. Folia Ophthalmol Jpn 1979; 30: 841-9.

3 Yamaguchi T, Kanai A, Tanaka M. Bullous keratopathy after anterior/posterior radial keratotomy for myopia and myopic astigmatism. Am J Ophthalmol 1982; 93: 600-6.

4 Fyodorov SN, Durnev VV. Anterior keratotomy method application with the purpose of surgical correction of myopia. Pressing problems of ophthalmosurgery. Moscow Press, 1977.

5 Waring GO, Moffitt SD, Gelender $\mathrm{H}$,et al. Rationale for design of the national eye institute prospective evaluation of radial keratotomy (PERK) study. Ophthalmology 1983; 90: 40-58.

6 Jones RF, Maurice DM. New methods of measuring the rate of aqueous flow in man with fluorescein. Exp Eye Res 1966; 5: 208-20. 
7 Hull DS, Farkas S, Green K, Laughter L, Elijah D, Bowman K. Radial keratotomy effect on cornea and aqueous humor physiology in the rabbit. Arch Ophthalmol 1983; 101: 479-81.

8 Van Horn DL, Sendele DD, Seidman S. Regenerative capacity of the corneal endothelium in rabbit and cat. Invest Ophthalmol Vis Sci 1977; 16: 597-613.

9 Hull DS, Farkas S, Green K, Laughter L, Bowman K. Radial keratotomy and corneal permeability in owl monkey. Acta Ophthalmol (Kbh) 1983; 61: 240-9.

10 Beatty RF, Smith RE. Corneal endothelial cell permeability to fluorescein following radial keratotomy in owl monkeys. Invest Ophthalmol Vis Sci 1986; 27 (suppl): 62.

11 Zimmerman TJ, Krupin T, Grodzki W, Waltman SR. The effect of suture depth on outflow facility in penetrating keratoplasty. Arch Ophthalmol 1978; 96: 505-6.

12 Yamaguchi T, Asbell PA, Ostrick M, Safir A, Kissling GE, Kaufman HE. Endothelial damage in monkeys after radial keratometry performed with a diamond blade. Arch Ophthalmol 1984; 102: 765-9.

13 Dunn S, Jester JV, Arthur J, Smith RE. Endothelial cell loss following radial keratometry in a primate model. Arch Ophthalmol 1984; 102: 1666-70.

14 Asbell PA, Obstbaum S, Justin N. Peripheral corneal endothelial evaluation post radial keratometry in PERK patients. Ophthalmology 1984; 91 (suppl): 122.

Accepted for publication 20 February 1987. 